\title{
Sustainable use of mineral and biofertilizers in the production of faba bean (Vicia faba) grown on calcareous soil.
}

\author{
Sherif, K.F ${ }^{1}$, M.E. Mourcy and A.M. Awad ${ }^{2}$
}

\begin{abstract}
To evaluate the effect of minimizing $N, P$ and $K$ fertilization levels in the presence of biofertilizers, two field experiments were conducted during the two successive winter season of $2003 / 04$ and $2004 / 05$ at the irrigated research experimental farm of Nubaria. The experimental design was a randomized complete blocks design (RCBD). Main plots consisted of three $\mathbf{N}, \mathbf{P}$ and $\mathrm{K}$ combination levels $($ low $=\mathrm{L}$, medium $=\mathrm{M}$, and high=H). Meanwhile, the sub-plots consisted of four biological fertilization treatments: control (without inoculation) inoculation with Rizobia (R), infection with Arbuscular Mycorrhiza (AM) and co-inoculation and infection $(\mathrm{R}+\mathrm{AM})$.

The results showed that plant height, GP (green pod) yield, and seed yield (SY) of fababean were responded significantly to the mineral fertilization. Inoculation with microorganisms increased biological yield (BY), SY, and staw yield (StY) of faba bean in the two growing season. Nitrogen use efficiency (NUE), phosphorous use efficiency (PUE), and potassium use efficiency (KUE) increased with decreasing fertilizer rate. With high fertilizer level, the coupled inoculation $(\mathrm{R}+\mathrm{AM})$ recorded the highest NUE, PUE, and KUE. Soil $\mathrm{NH}_{4}^{+}$concentration increased significantly with the coupled inoculation $(R+A M)$ while it decreased significantly with (R) and (AM) compared to uninoculated. In contrary, Soil $\mathrm{NO}_{3}^{-}$increased significantly with (R), (AM), and (R+AM).
\end{abstract}

Nutrients uptake by faba bean plants increased significantly with different levels of mineral fertilizers. The coupled inoculation had remarkable influences on all nutrients uptake than single biofertilizers. Concerning, the interaction of mineral and biofertilizers, it was noticed that (R) significantly increased $\mathrm{N}$ uptake in straw with $\mathrm{L}$ and $\mathrm{M}$ NPK. Phosphorous uptake was increased significantly in both straw and seeds with (AM) inoculation at all NPK fertilizer levels. For the coupled inoculation it was noticed that $(\mathbf{R}+\mathbf{A M})$ increased significantly $N$ uptake in straw at the three fertilizer levels. Nitrogen, $P$ and $K$ uptake in the whole plants was also significantly increased by the interaction between mineral and biofertilizers. The combined treatment (high NPK+ coupled inoculation) produced the highest $P$ and $K$ in plants, while, the L-NPK with coupled inoculation recorded the highest $N$ uptake for the whole plants.

\section{INTRODUCTION}

One of the major concerns, in today's world, is the contamination of agricultural soil. The extensive use of chemical fertilizers and pesticides has caused tremendous harm to the environment. An answer to this is the biofertilizer, an environmentally friendly fertilizer now used in most countries.

In recent years, concepts of integrated plant nutrient management (IPNM) have been developed, which emphasize maintaining and increasing soil fertility by optimizing all possible sources (organic and inorganic) of plant nutrients required for crop growth and quality. This is done in an integrated manner appropriate to each cropping system and farming situation. Improvement in agricultural sustainability requires optimal use and management of soil fertility and soil physical properties, both of which rely on soil biological processes and soil biodiversity. In this context, the long-lasting challenges in soil microbiology are development of effective methods to know the types of microorganisms, and to determine functions which the microbes perform in situ (Tilak, 2005).

Bio-fertilizers are organisms that improve soil fertility and enhance nutrients and water uptake in deficient soils, thereby aiding in better establishment of plants. It also secretes growth substances and antifungal chemicals, as well as improves seed germination and root growth. Moreover, biofertilizers will help for solving such problems as increased salinity of the soil and chemical run-offs from the agricultural fields.

Nitrogen fixation by leguminous crops is a relatively low-cost alternative to $\mathrm{N}$ fertilizer for small-holder farmers in developing countries. It can also maintain soil fertility and can be of benefit to the successive crop. Legumes have considerable potential in crop rotations in sustainable agricultural systems in maintaining soil fertility and thus reducing the need for nitrogen fertilizer. Reduced use of nitrogen fertilizer can decrease nitrate leaching from soils and so can reduce eutrophication, which is a major environmental problem worldwide (Amanuel et al. 2000).

\footnotetext{
${ }^{1}$ Soil and Water Science Department, Faculty of Agriculture, Alexandria University, El-Shatby 21545, Alexandria, Egypt.

2 Soil Fertility \& Plant Nutrition Dept. SWERI, ARC, Giza, Egypt.

Received May 20 ,2007 Accepted June 25, 2007.
} 
Phosphorus is one of the major plant nutrients limitunavailable to plants (Rodriguez and Fraga, 1999). Most agricultural soils contain large reserves of $\mathrm{P}$, a considerable part of which has accumulated as a consequence of regular application of chemical fertilizers. However, a large proportion of inorganic phosphate added to soil is rapidly fixed as insoluble forms soon after application and becomes unavailable to plants. The superphosphate fertilizer, which contains about $15 \%$ of $\mathrm{P}_{2} \mathrm{O}_{5}$, normally loses its available $\mathrm{P}$ proportion when it comes in contact with soil minerals containing calcium carbonates (Lindsay, 1979)

A substantial number of bacterial species, mostly those associated with the plant Rizosphere, may exert a beneficial effect upon plant growth (Glick, 1995). This group of bacteria has been termed "plant growth promoting Rizobacteria" or PGPR (Igual, et al. 2001) and, among them, some phosphate-solubilizing bacteria (PSB) are already used as commercial biofertilizers for agricultural improvement (Subba, 1993). Therefore, for agronomic utility, inoculation of plants by target microorganisms at a much higher concentration than those normally found in soil is necessary to take advantage of their beneficial properties for plant yield enhancement.

Arbuscular mycorrhizal (AM) fungi positively affect the acquisition of mineral nutrients by the host plant by functionally increasing the absorptive surface of the root system. This has been demonstrated in case of phosphorus with numerous combinations of plant and AM fungal species (Smith and Read, 1997). It has also been shown that external AM hyphae are able to take up nitrogen both as $\mathrm{NH}_{4}{ }^{+}$(Frey and Schiepp, 1993) and $\mathrm{NO}_{3}^{-}$(Tobar et al, 1994) and translocate $\mathrm{N}$ to the host plant in considerable amount. Barea et al. (1989) found that external AM hyphae may utilize $\mathrm{N}$ sources that are not available to the roots alone.

An alternative approach for the use of phosphatesolubilizing bacteria, as microbial inoculants, is the use of mixed cultures or co-inoculation with other microorganisms. In this regard, studies on the isolation and selection of microorganisms with ability to promote higher solubilization of phosphorous have been carried out in many works, especially because of the possibility of interaction with microorganisms involved in biological nitrogen fixation (Igual et al., 2001). ElSerafei et al. (2006) reported that there was a slight additional increase in grain and straw yields of wheat when a biofertilizer was applied along with $\mathrm{N}$ fertilizer. The $\mathrm{N}$ fixing bacteria $+\mathrm{P}$ solublizing bacteria combination increased these parameters over the $\mathrm{N}$ fertilizer control. The effect of the $\mathrm{N}$ biofertilizer in increasing grain yields was equivalent to $\mathrm{N}$ fertilizer application rate of about $13 \mathrm{~kg} \mathrm{~N} \mathrm{ha}^{-1}$.

This study was carried out to evaluate the effect of minimizing $\mathrm{N}, \mathrm{P}$ and $\mathrm{K}$ fertilization levels in the presence of biofertilizers including interaction of $\mathrm{N}_{2}$ fixing bacteria $(\mathrm{R})$ and $\mathrm{P}$ solubility enhancing fungi (AM) with three different levels of mineral fertilizer (L, $\mathrm{M}$, and $\mathrm{H}$ ) in a soil with low level of available $\mathrm{N}$ and $\mathrm{P}$, on Faba bean (Vicia faba, L.) yields, plant characteristics, total $\mathrm{N}, \mathrm{P}$ and $\mathrm{K}$ in plant at harvesting time, the response of mineral $\mathrm{N}, \mathrm{P}$ and $\mathrm{K}$ availability in soil will be evaluated.

\section{MATERIALS AND METHODS}

Two field experiments were conducted during the two successive winter season of 2003/04 and 2004/05.

\section{1-Experimental site}

This study was conducted at the irrigated research experimental farm of Nubaria Agriculture Research Station, North Tahrer, west Nubaria region under the conditions of newly reclaimed calcareous soils irrigated by the surface irrigation system. The used soil is sandy clay loam, has medium permeability while it was well drained. The physical and chemical characteristics of the surface soil $(0-20 \mathrm{~cm})$ and sub-surface soil (20-40) were determined according to Page et al. (1982) and Klute (1986) and were illustrated in Table (1).

Table 1. The physical and chemical characteristics of the surface and sub-surface soil

\begin{tabular}{|c|c|c|}
\hline Characteristics & $\begin{array}{c}\text { surfac } \\
\text { e soil }\end{array}$ & $\begin{array}{c}\text { sub-surface } \\
\text { soil }\end{array}$ \\
\hline $\mathrm{pH}$ & 8.2 & 8.15 \\
\hline $\mathrm{EC} \mathrm{dS} \mathrm{m}{ }^{-1}$ & 1.3 & 1.42 \\
\hline$\% \mathrm{CaCO}_{3}$ & 25.3 & 21.4 \\
\hline$\%$ O.M & 0.33 & 0.36 \\
\hline $\mathrm{KCl}$ extractable $\mathrm{NO}_{3} \mathrm{mg} \mathrm{kg}^{-1}$ & 23.50 & 29.20 \\
\hline $\mathrm{NaHCO}_{3}$ extractable $\mathrm{P} \mathrm{mg} \mathrm{kg}^{-1}$ & 12.10 & 6.55 \\
\hline $\mathrm{NH}_{4} \mathrm{OAC}$ extractable $\mathrm{K} \mathrm{mg} \mathrm{kg}{ }^{-1}$ & 380.0 & 320.50 \\
\hline
\end{tabular}

\section{2-Materials used}

Seeds of Faba Bean Vicia faba variety Giza blanka were sown. Ammonium nitrate $(33.5 \% \mathrm{~N})$, single superphosphate $\left(\begin{array}{lll}15.5 \% & \mathrm{P}_{2} \mathrm{O}_{5}\end{array}\right)$ and potassium sulfate $\left(48 \% \mathrm{~K}_{2} \mathrm{O}\right)$ fertilizers were used as sources of $\mathrm{N}, \mathrm{P}$ and $\mathrm{K}$. Two strains of biofertilizers were inoculated to faba bean seeds. Rizobium meleloti (R) strain was inoculated to seeds as good root-nodule bacteria for $\mathrm{N}_{2}$ fixation, whereas Arbuscular Mycorrhiza (AM) inocula spores (mixture of Glomus macrocarpium, infected root fragments and mycelium) were used to infect seeds of faba bean as appropriate strains.

\section{3-Experimental Design}

The experiment layout was a randomized complete blocks design (RCBD) with four replicates distributed 
randomly. Main plots consisted of three $\mathrm{N}, \mathrm{P}$, and $\mathrm{K}$ combination levels (low, medium and high). Meanwhile, the sub-plots consisted of four biological fertilization treatments; control (without inoculation) inoculation with (R), infection with (AM) and finally dual inoculation and infection with ( $\mathrm{R}+\mathrm{AM})$.

\section{4-Field Experiments}

The area of experimental plot was $18 \mathrm{~m}^{2}(6 \mathrm{~m} \times 3 \mathrm{~m})$, each sub-plot contains 10 rows with $3 \mathrm{~m}$ length. The fertilizers: N, P and K were applied with (L), (M) and $(\mathrm{H})$ rates. Nitrogen was fertilized with the rates of 20,40 and $60 \mathrm{kgN} \mathrm{fed}^{-1}$, $\mathrm{P}$ with the rates of $15,22.5$ and $30 \mathrm{~kg}$ $\mathrm{P}_{2} \mathrm{O}_{5}$ fed $^{-1}$ and $\mathrm{K}$ with rates of 24,36 and $48 \mathrm{~kg} \mathrm{~K}_{2} \mathrm{O}$ fed

1. $\mathrm{P}$ and $\mathrm{K}$ fertilizers were incorporated during land preparation in the soil surface for all plots according two fertilization treatments. Treatments included two factors: (i) three mineral NPK fertilization levels consisted of 20-15-24, 40-22.5-36 and 60-30-48, and (ii) four inoculation and infestation treatments with $\mathrm{R}$ and $\mathrm{AM}$ included: un-inoculated (control), inoculated with $\mathrm{R}$, infested with $\mathrm{AM}$ and coupled inoculation and infestation with $\mathrm{R}+\mathrm{AM}$. Seeds of Faba bean in the two experiments were sown in the first week of November 2003 and 2004 during the two growing seasons. All plots received 2 equal applications of $\mathrm{N}$ fertilizer according to $\mathrm{N}$ fertilization level as $\mathrm{NH}_{4} \mathrm{NO}_{3}$.

Plant samples were taken 75-80 days after planting to determine (GP). Faba bean plant characteristics, (BY), (SY) and (StY) and yield components were measured 125 days from planting.

Samples of green pods, seeds and straw at harvesting time were dried in a forced-air dryer at $65-70^{\circ} \mathrm{C}$. After grinding and wet digested using concentrated sulfuric acid and hydrogen peroxide (FAO, 1980) N, P and K were determined according to Westerman (1988). Finally concentrations and uptake of N, P and $\mathrm{K}$ were calculated.

Nitrogen, phosphorus and potassium use efficiencies (NUE, PUE and KUE) were calculated according to formula of Huggins and Pan (1993): N-, P-, K-UE= seed yield $\mathrm{fed}^{-1} \div$ added nutrient fertilizer $\mathrm{kg} \mathrm{fed}^{-1}$.

\section{5-Statistical Analysis}

Data of the present study were statistically analyzed using MSTAT-C software (Freed, 1988). The comparisons among means of the different treatments were carried out; using the Duncan's multiple range tests as illustrated by Gomez and Gomez (1983).

\section{RERSULTS AND DISCUSSION}

The used experimental soil is calcareous sandy clay loam with low content of both organic matter and available NPK indicating poor fertility status (Table 1).

\section{1- Effect of different treatments on faba bean biomass}

Table (2) showed that plant height, green yield (GP), and seed yield (SY) of fababean were responded significantly to the mineral fertilization. Plant height was increased by about 3 and 2\% with the treatment of Med. NPK, and high NPK, respectively. Whereas, High NPK, and Med. NPK increased the (GP) yield by 94 and 31\%, respectively. Indeed, the (SY) was increased by 8 and $18 \%$ with $\mathrm{M}$ and $\mathrm{H}-\mathrm{NPK}$, respectively.

The un-inoculated (control) showed the lowest growth rate of all inoculation treatments with yield characteristics Table (2). Inoculation with microorganisms increased BY, SY, and StY of faba bean in the two growing seasons. Significant increase in faba bean yields (BY, SY, and StY) with (R) reached to 3,1 , and $5 \%$, respectively, whereas, (AM) increased the same component by 1,7 , and $2 \%$, respectively. It is obvious to mention that (SY) showed remarkable increase with (AM) treatment.

In case of coupled inoculation and infestation with $(\mathrm{R}+\mathrm{AM})$, a significant increase was recorded and reached 14, 19, and $12 \%$ for BioY, SY, and StY, respectively.

The results of interaction indicated that faba bean productivity increased insignificantly over control treatments except for seed index which increased significantly. The maximum seed index were recorded with M-NPK+(AM)

For L. fertility treatments, the present results indicated that faba bean responded negatively to inoculation. This may be due to competition for nutrients between plants and different types of microorganisms. The same trend was observed by Gavito and Varela, (1995).

\section{2-Nutrients use efficiency}

Nitrogen, phosphorous and potassium use efficiencies (NUE, PUE, and KUE) are presented in Figs 1, 2, and 3. It is noted that NUE, PUE, and KUE increased with decreasing fertilizer rates. This increasing may be due to the beneficial and enhancement of microorganisms in supplying fababean with nutrients.

In case of high fertilizer level, the coupled inoculation $(\mathrm{R}+\mathrm{AM})$ recorded the highest NUE, PUE, and KUE (27.5, 54.9, and 34.3). However, the treatment of $(\mathrm{R})$ reached 26.2, 52.5, and 32.8, and the treatment of

In contrary, with $\mathrm{M}$ and $\mathrm{L}$ fertilizer rate the (AM) treatment recorded higher increasing than $(\mathrm{R})$ treatment. This increase could be attributed to the effectiveness of (AM) hyphae to take up $\mathrm{N}$ and $\mathrm{K}$ as well as $\mathrm{P}$ (Johansen, 
1999). The same trend was observed by Awad et al. (2004) (AM) reached 25.3, 50.6, and 31.6 for NUE, PUE, and KUE, respectively.

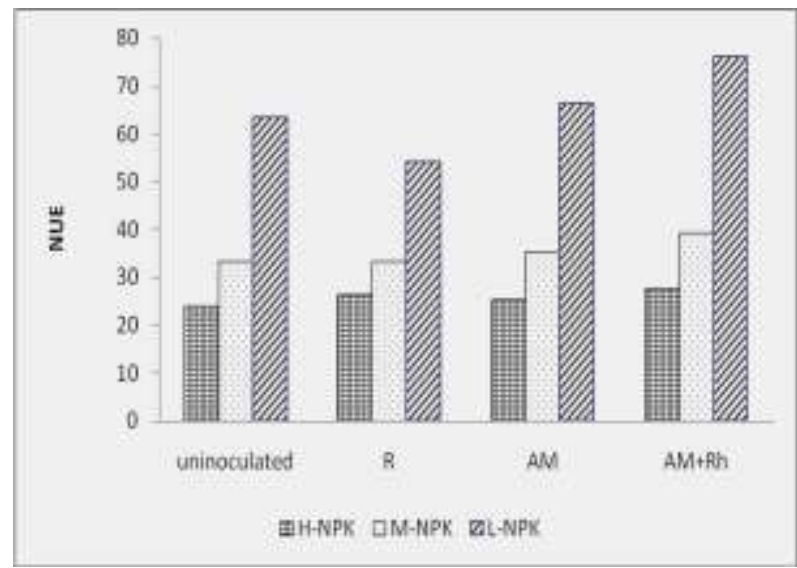

Fig.1 Effect of inoculation with (R), (AM), and (AM+R) on NUE under three mineral fertilizer levels.

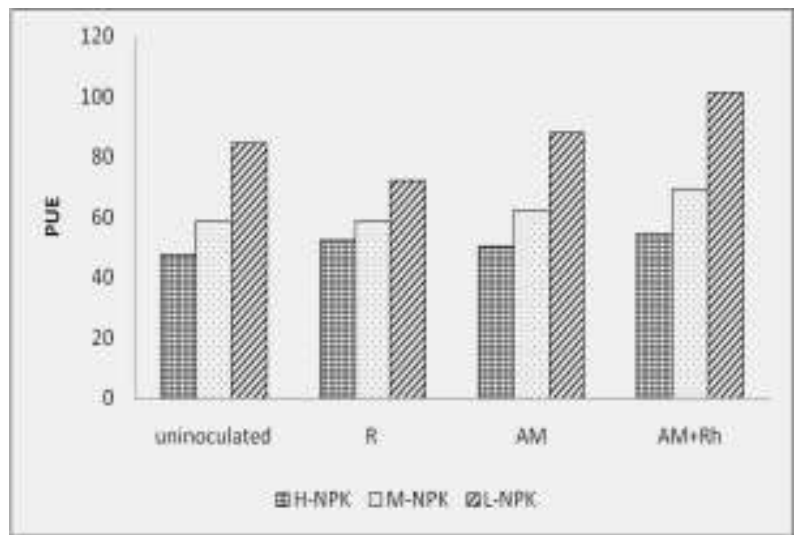

Fig.2 Effect of inoculation with (R), (AM), and (AM+R) on PUE under three mineral fertilizer levels.

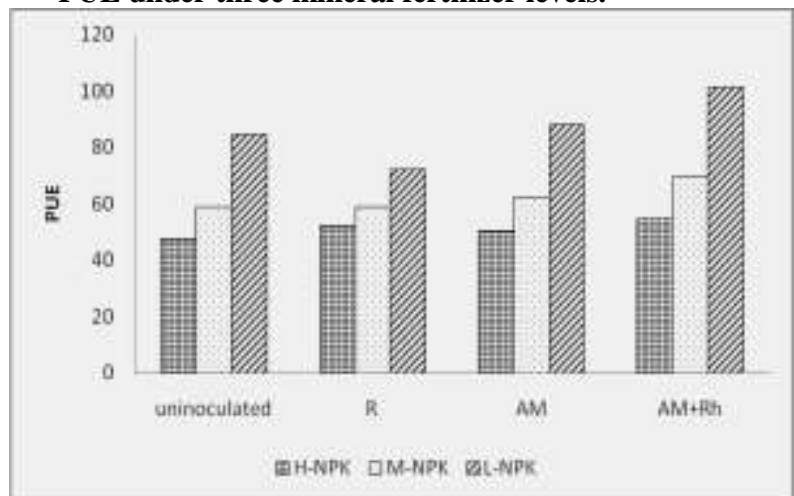

Fig.3 Effect of inoculation with (R), (AM), and (AM+R) on KUE under three mineral fertilizer levels.

\section{3-Residual soil nutrients}

Regarding the effect of mineral fertilization, data in Table (3) showed that $\mathrm{NH}_{4}{ }^{+}$concentration in soil was insignificantly affected by the level of $\mathrm{N}$ fertilizer applied, while $\mathrm{NO}_{3}$ was increased significantly with increasing $\mathrm{N}$ fertilizer level. This increase reached $12 \%$ at M-NPK. The same trend was observed with available $\mathrm{P}$ and exchangeable $\mathrm{K}$. The increase in soil nutrients means that the fertilizers applied were over plant requirement.

Concerning, the effect of biological fertilization, data in Table (3) showed that soil $\mathrm{NH}_{4}^{+}$concentration increased significantly by $2 \%$ with the coupled inoculation $(\mathrm{R}+\mathrm{AM})$ while it decreased significantly by 0.4 and $8 \%$ with (R) and (AM) compared to uninoculated, respectively. In contrary, $\mathrm{NO}_{3}{ }^{-}$increased significantly with (R), (AM), and (R+AM). This may be due to that external hyphae and ryzobium seem to prefer $\mathrm{NH}_{4}{ }^{+}$to $\mathrm{NO}_{3}{ }^{-}$. Soil available $\mathrm{P}$ and exchangeable $\mathrm{K}$ had the same trend as soil $\mathrm{NO}_{3}{ }^{-}$. The depletion of soil $\mathrm{NH}_{4}$ concentration induced by the presence of $(\mathrm{R})$ or $(\mathrm{AM})$ is due to the parallel utilization and transport of $\mathrm{NH}_{4}{ }^{+}$by the external hyphae or ryzobium. This may indicate that they absorbed a considerable $\mathrm{NH}_{4}$, and this demonstrates the decreasing in plant height with $(\mathrm{R})$ and (AM) as shown in Table (2). Evidence has been given for (R) and (AM) fungal utilization of $\mathrm{NH}_{4}$ (Johansen, 1999). In case of coupled inoculation, this depletion was not observed.

Table (3) illustrated also the interaction between different levels of NPK and the biological fertilizers inoculation. It is clear that (R) depleted soil $\mathrm{NH}_{4}{ }^{+}$at LNPK level due to the competition between plant uptake and (R) acquisition, and at H-NPK level it decreased. This may be due to the increasing in tillers number Table (2). However at M-NPK level soil $\mathrm{NH}_{4}{ }^{+}$ increased.

The (R) induced an increased about $21 \%$ relative to the un-inoculated at the H-NPK while the increasing was about $6 \%$ only at M-NPK level. This increase may be due to the growth substances secreted by microorganisms which solubilize nutrients in the rhizosphere.

On the other hand, (AM) caused depletion in soil $\mathrm{NH}_{4}{ }^{+}$at the three levels of mineral fertilizers compared with the un-inoculated treatment. The same trend was observed with the coupled inoculation $(\mathrm{R}+\mathrm{AM})$ except at L-NPK level, Soil $\mathrm{NH}_{4}{ }^{+}$increased by $8 \%$ relative to the un-inoculated. This is may be due to the decreasing in plant height (Table2) which reflects the decreasing of $\mathrm{N}$ uptake by plants.

In contrary, Soil $\mathrm{NO}_{3}$ increased with increasing NPK level and this confirmed the previous discussion that (R) 
Table3. The amount of residual soil mineral N, available $P$ (Av.P) and Exchangeable $K$ (Exch.K) as affected by levels of $\mathbf{N}, \mathbf{P}$, and $\mathrm{K}$ fertilization and biological fertilizers inoculation.

\begin{tabular}{|c|c|c|c|c|c|}
\hline \multicolumn{2}{|r|}{ Treatment } & \multicolumn{2}{|c|}{ Mineral N } & \multirow{2}{*}{ Av. $P$} & \multirow{2}{*}{ Exch. K } \\
\hline Min. F & Bio. $\mathbf{F}$ & $\mathbf{N H}_{4}$ & $\mathrm{NO}_{3}$ & & \\
\hline & & \multicolumn{4}{|c|}{$\mu \mathrm{g} \mathrm{g}^{-1}$} \\
\hline L- NPK & & 29.11 & 32.73 & 22.05 & 313.33 \\
\hline M-NPK & & 28.79 & 36.93 & 24.92 & 374.58 \\
\hline H-NPK & & 29.11 & 36.30 & 25.93 & 387.08 \\
\hline & LSD0.05 & $\mathrm{ns}$ & 3.36 & 0.93 & 47.52 \\
\hline & Un-inoculated & 29.50 & 32.50 & 21.99 & 337.22 \\
\hline & Rhizobia (R) & 29.36 & 36.50 & 23.01 & 351.67 \\
\hline & Mycorrhiza (AM) & 27.03 & 35.50 & 25.23 & 356.11 \\
\hline & $\mathrm{R}+\mathrm{AM}$ & 30.14 & 36.44 & 26.90 & 388.33 \\
\hline & LSD0.05 & 1.80 & 2.13 & 1.31 & 12.06 \\
\hline & Un-inoculated & 28.49 & 29.05 & 19.93 & 280.00 \\
\hline \multirow[t]{4}{*}{ L- NPK } & Rhizobia (R) & 28.13 & 33.08 & 21.77 & 315.00 \\
\hline & Mycorrhiza (AM) & 28.93 & 31.62 & 22.85 & 323.33 \\
\hline & $\mathrm{R}+\mathrm{AM}$ & 30.90 & 37.17 & 23.66 & 335.00 \\
\hline & Un-inoculated & 29.48 & 35.82 & 22.59 & 365.00 \\
\hline \multirow[t]{4}{*}{ M-NPK } & Rhizobia (R) & 30.80 & 38.87 & 23.18 & 353.33 \\
\hline & Mycorrhiza (AM) & 25.47 & 35.53 & 26.07 & 376.67 \\
\hline & $\mathrm{R}+\mathrm{AM}$ & 29.42 & 37.50 & 27.85 & 403.33 \\
\hline & Un-inoculated & 30.52 & 32.57 & 23.44 & 366.67 \\
\hline \multirow[t]{4}{*}{ H-NPK } & Rhizobia (R) & 29.15 & 38.60 & 24.30 & 386.67 \\
\hline & Mycorrhiza (AM) & 26.69 & 39.35 & 26.77 & 368.33 \\
\hline & $\mathrm{R}+\mathrm{AM}$ & 30.10 & 34.67 & 29.20 & 426.67 \\
\hline & LSD0.05 & 3.12 & 3.69 & 2.27 & 20.90 \\
\hline
\end{tabular}

Min F: mineral NPK fertilizers level

Bio.F: biological fertilizers inoculation

ns : statistically not significant

preferred $\mathrm{NH}_{4}^{+}$than $\mathrm{NO}_{3}^{-}$. The increase in soil $\mathrm{NO}_{3}{ }^{-}$ concentration with (AM) inoculation was less than with (R), this nay be due to the (AM) can absorb $\mathrm{NO}_{3}$ as well as $\mathrm{NH}_{4}^{+}$.

Available P increased by 9, 2 and $3 \%$ with $\mathrm{L}, \mathrm{M}$, and H-NPK level, respectively in plant inoculated with (R) compared by un-inoculated. The highest soil $\mathrm{P}$ concentration recoded at L-NPK level. This may be related to the lower plant uptake at this level.

The same trend was observed with (AM) which was higher than (R). This was attributed to the effectiveness of (AM) to solubilize P.

Exchangeable $\mathrm{K}$ also had the same trend as available $P$ with NPK levels. This means that using of biofertilizer could improve soil fertility.

\section{4-Nutrient uptake}

Nitrogen, $\mathrm{P}$, and $\mathrm{K}$ uptake by faba bean plants increased significantly with different levels of mineral fertilizers (Table4). The highest value of NPK was noticed when plants fertilized with H- NPK fertilizers except for $\mathrm{N}$ uptake in straw where the highest value was obtained with M-NPK. This may be due to that heavy $\mathrm{N}$ fertilizer applications reduced yield as well as $\mathrm{N}$ uptake. These results matched well with those of Barakat and Gabr, (1998) who found that tomato fruit yield usually increased with moderate $\mathrm{N}$ dressings.

Regarding the effect of biological fertilizers, it was noticed in Table (4) that (R) increased significantly N, $\mathrm{P}$, and $\mathrm{K}$ uptake in straw, seeds and total plants except $\mathrm{K}$ uptake in straw which decreased in rhizobia treated plants. This may be referred to the dilution effect, as the plant dry matter increased due to $(\mathrm{R})$ inoculation. On the other hand, (AM) significantly increased NPK uptake in straw, seeds and total plants, except for $\mathrm{N}$ uptake in straw. This could be due to the effect of (AM) inoculation in solubilizing $\mathrm{P}$ and increased root surface area to take up different nutrient efficiently. Similar results were obtained by Koreish et al., 2004. Using coupled inoculation ( $\mathrm{R}+\mathrm{AM})$ significantly resulted in highest $\mathrm{N}, \mathrm{P}$, and $\mathrm{K}$ uptake in straw, seeds, and total plant compared with the un-inoculated plants. The coupled inoculation had remarkable influences on all traits than single biofertilizers. The improving effects of 
biofertilizers on $\mathrm{N}, \mathrm{P}$, and $\mathrm{K}$ uptake can be related to the role of $\mathrm{N}_{2}$-fixing bacteria as well as (AM) in increasing nutrient uptake. Moreover, the hormonal exudates of the biofertilizers bacteria can modify root growth, morphology, and physiology, resulting in more absorption of nutrient.

Concerning, the interaction of mineral and biofertilizers, it is noticed in Table (4) that (R) significantly increased $\mathrm{N}$ uptake in straw with $\mathrm{L}$ and $\mathrm{M}$ NPK by 16 and $11 \%$ relative to un-inoculated, while, it decreased by $2.5 \%$ at high NPK. This may be due to the decrease in (R) activity with H-NPK application. In the same time, $\mathrm{P}$ uptake was significantly increased by 10 , 8 , and $2.5 \%$ relative to un-inoculated. In contrary, $(\mathrm{R})$ significantly decreased $\mathrm{K}$ uptake in straw with the three $\mathrm{N}, \mathrm{P}$, and $\mathrm{K}$ fertilizer levels. Meanwhile, it increased significantly $\mathrm{K}$ uptake in seeds by 9 and $13 \%$ relative to un-inoculated plants with L and M-NPK, respectively.

Phosphorous-uptake was increased significantly in both straw and seeds with (AM) inoculation at all $\mathrm{N}, \mathrm{P}$, and $\mathrm{K}$ fertilizer levels. The observed increase in seeds was 36,29 , and $26 \%$ relative to un-inoculated plants with the three fertilizer levels, L, M, and $\mathrm{H}$, respectively. While, the P-uptake observed in straw was lower (42, 15 , and $5 \%$ ) relative to un-inoculated at the three fertilizer levels, respectively. This could be to that plants stored $\mathrm{P}$ in seeds.

For the coupled inoculation, it was noticed in Table (4) that $(\mathrm{R}+\mathrm{AM})$ increased significantly $\mathrm{N}$ uptake in straw by 35,15 , and $11 \%$ relative to un-inoculated plants at the three fertilizer levels, respectively; and this confirm the previous results for increasing NUE at lower $\mathrm{N}$ fertilizer applications. The $\mathrm{P}$ uptake was increased significantly in seeds than in straw with coupled inoculation compared to un-inoculated except for MNPK. Also, coupled inoculation increased significantly $\mathrm{K}$ uptake in both straw and seeds with all fertilizers levels.

Nitrogen, P, and K uptake in the whole plants was also significantly increased by the interaction between mineral and biofertilizers. The combined treatment (high $\mathrm{NPK}+$ coupled inoculation) produced the highest $\mathrm{P}$ and $\mathrm{K}$ in whole plants. While, the L-NPK with coupled inoculation recorded the highest $\mathrm{N}$ uptake for the whole plants.

Finally, it could be concluded that biofertilizers improve soil fertility and enhance nutrients uptake in deficient soil, thereby aiding in better establishment of plants. Thus, biofertilizers are important if we are ensure a healthy future for the generations to come.

\section{REFERENCES}

Amanuel, G; R. F. Kuhne; D. G. Tanner; P. L. Vlek. 2000

. Biological nitrogen fixation in faba bean (Vicia faba L.) in the Ethiopian highlands as affected by $\mathrm{P}$ fertilization and inoculation. Bio. and Fert. of Soils 32(5): 353-359.

Awad, A.M, E.A. Koreish, and M.A. Mourad. 2004. Alfalfa and wheat productivity as affected by intercropping, biofertilizers and sustainable use of saline water at siwa oasis. Minufiya J. Agric. Res. 29(6) 1431-1452.

Barakat, M.A. and S.M. Gabr. 1998. Effect of different biofertilizers types and nitrogen fertilizer levels on tomato plants. Alex. J. Agric. Res. 43(1): 149-160.

Barea, J.M, C. Azcon, and R. Azcon. 1987. Vescular arbscular Mycorrhiza improve both symbiotic $\mathrm{N}_{2}$ fixation and $\mathrm{N}$ uptake from soil as assessed with a ${ }^{15} \mathrm{~N}$ technique under field conditions. New Phytol.106: 717-725.

El-Sirafei, Z. M., H. J. Woodard, E. M. El-Norjar. 2006. Contribution of biofertilizers and fertilizer nitrogen to nutrient uptake and yield of Egyptian winter wheat. J. Plant Nutr. 29: 587 - 599.

FAO. 1980. Soil and Plant Analysis as Basis of Fertilizer Recommendations. Cottenie, A. (Ed.) Soils bulletin No.38 (2). Rome.

Freed, R. D. 1988. MSTAT-C: A microcomputer program for the design, management, and analysis of agronomic research experiments. Michigan State Univ. USA.

Frey, B. and H. Schiepp. 1993. Acquisition of nitrogen by external hyphae of arbuscular Mycorrhiza fungi assossiated with zea mays. New Phytol.124: 212-230.

Gavito, M.E. and L.Varela. 1995. Response of maize to single and mixed species inocula of arbuscular Mycorrhizal fungi. Plant and Soil. 176:101-105.

Glick B.R., The enhancement of plant growth by free living bacteria, Can. J. Microbiol. 41 (1995) 109-117.

Gomez, C.A. and A.A. Gomez. 1983. Statistical procedure for Agricultural Research ( $2^{\text {nd }}$ ed.). An international Rice Research Institute Book. A Wiley-Inter science.

Huggins; D.R. and W.L. Pan. 1993. Nitrogen efficiency component analysis:An evaluation of cropping system differences in productivity. Agron. J. 85:898-905.

Igual, J.M., A. Valverda,.E. Cervantes, E. Encarna. 2001. Phosphate solubilizing bacteria as inoculants for agriculture. Agronomie. 21: 561-568.

Johansen, A. 1999. Depletion of soil mineral $\mathrm{N}$ by roots of Cucumis sativus L. colonized or not by arbuscular Mycorrhizal fungi. Plant and Soil. 209: 119-127.

Klute, A. (ed.) 1986. Methods of Soil Analysis. Part 1. Book series No. 9. American Soc. of Agron. and Soil Sci. Soc. America, Madison, Wisconsin, USA.

Koreish, E.A; M.E. El-Fayoumy; H. Ramadan; and W.H. Mohamed. 2004. Interaction effect of organic and mineral 
fertilization on faba bean and wheat productivity in calcareous soils. Alex. J. Agric. Res. 49(2): 101-114.

Lindsay W.L., Chemical Equilibrium in Soil, John Wiley and Sons, New York, 1979.

Mstat-c software.1981. Russel. D.F., Crop and Soil

Sciences Department Michigan State University. Version 1.2. Page, A.L. (ed.) 1982. Methods of Soil Analysis. Part 2. Book series No 9. American Soc. of Agron. and Soil Sci. Soc. Am. Madison, Wisconsin. USA.

Rodríguez H., Fraga R. 1999. Phosphate solubilizing bacteria and their role in plant growth promotion. Biotechnol. Adv. 1: 319-339.

Smith, S.E, and D.J. Read. 1997. MychorRizal symbiosis. $2^{\text {nd }}$ ed. San Diago, USA. P.605.
Subba Rao N.S. 1993. Biofertilizers in Agriculture and Forestry, Oxford and IBH Publishing Co. Pvt. Ltd. New Delhi.

Tilak, K., N. Ranganayaki, K. Pal, R. De, and A. Saxena. 2005. Diversity of plant growth and soil health supporting bacteria. Current Science. 89: 136-150

Tobar, R., R. Azcon, and J.M. Barea. 1994. Improved nitrogen uptake and transport from ${ }^{15} \mathrm{~N}$-labelled nitrate by external hyphae of arbuscular Mycorrhiza under water-stressed conditions. New Phytol.126: 119-122.

Westerman, R.L. (ed.). 1990. Soil testing and plant analysis. Third edition, Soil Sci. Soc. Am. Book series No. 3. Soil Sci. Soc. Am. Madison, Wisconsin USA.

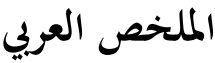

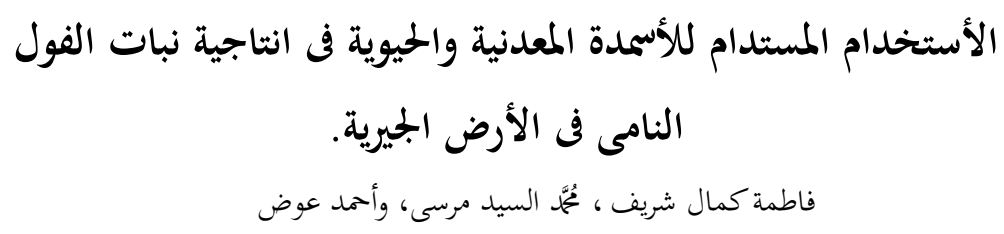


تفضل الأمونيوم عن النترات. وقد أخـذ الفوسفور المتـاح والبوتاسيوم نفس الاتحاه كما في حاله النترات.

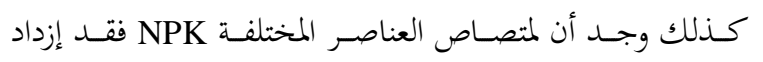
معنوياً بزيادة الأسمده المعدنيه المضافة.

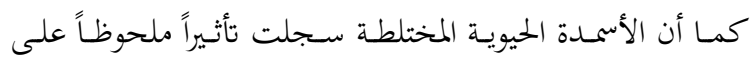
العناصـر الممتصسه NPK بواسطة النبـات أفضـل مـن السـماد الحيـوى

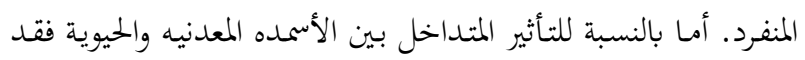

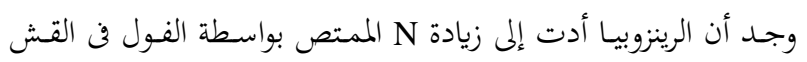
عند المستوى المنخفض والمتوسط بينما إزداد إمتصاص P مع الميكوزيزا

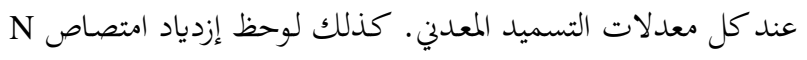

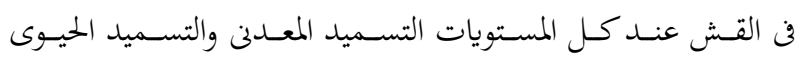
المختلط. وبحسـاب إمتصاص NPK فن النبـات الكامـل وجـد أنه إزداد مع التسميد عند مستويات التسميد المعدنى المختلفة.
لدراسـة تأثير إستخدام بعض الأسمـدة الحيويـة على التقليل مـن

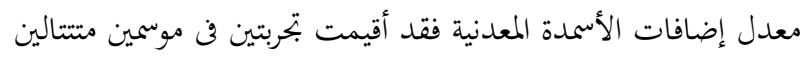

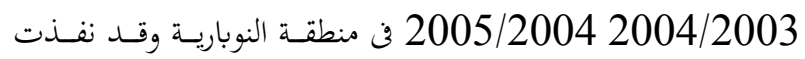

التجارب باستخدام تصميم القطاعات كاملة العشوائية RCBD .

N, P تضمنت المعاملات ثلاث معادلات من الأسمدة المعدنية and K

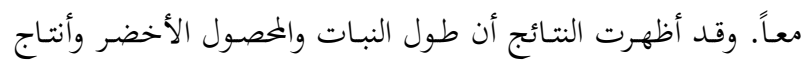

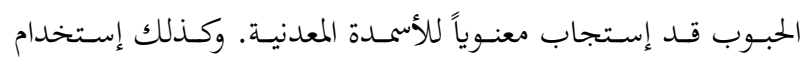
الأسمدة الحيوية أدت إلى زيادة BY,SY,STY خلابد المال الموسمين.

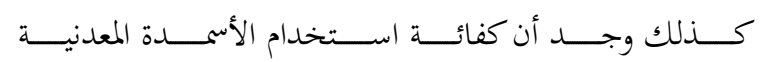

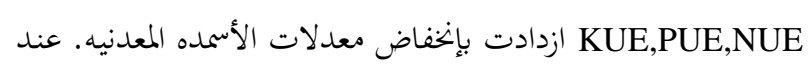

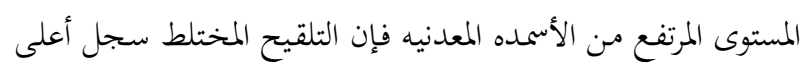

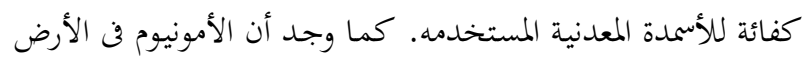
بعد الحصاد قد ازداد تركيزه معنويا في حالة الأسمدة الحيوية المختلطة، بينما انخفضت في الأسمدة الحيوية المنفردة. وعلى العكس فقـد ازداد تركيز النترات في جميع الأحسوال مما يدل على أن الميكوريزا 